\title{
MIR203A wt Allele
}

National Cancer Institute

\section{Source}

National Cancer Institute. MIR203A wt Allele. NCI Thesaurus. Code C82158.

The human MIR203A wild-type allele is located in the vicinity of $14 q 32.33$ and is approximately 110 bases in length. This allele, which encodes MIR203A pre-miRNA, plays a role in the regulation of gene expression. Alteration in the expression of this gene is associated with development of acute lymphoblastic leukemia, chronic myeloid leukemia and psoriasis. 